\title{
Marketing analytics: delineating the field while welcoming crossover
}

\author{
Anjala S. Krishen ${ }^{1}$ Maria Petrescu ${ }^{2}$
}

Published online: 21 November 2018

(C) Springer Nature Limited 2018

We were recently co-chairs of the Marketing Analytics and Big Data track, with Dr. Dawn Iacobucci (Vanderbilt University), at the Society for Marketing Advances 2018 Conference, in West Palm Beach. As part of the conference, the JMA offered an award for the best paper in the track to Dr. Aidin Namin and Dr. Yashar Dehdashti. We also participated in a special panel session entitled, "Advanced Analytics-The Impact on Marketing and Evolution from Descriptive to Prescriptive." The panel was organized by several researchers in the field, namely, Dr. Dana Harrison (East Tennessee State University), Dr. Haya Ajjan (Elon University), Dr. Joe Hair (University of South Alabama), Dr. Jeff Risher (University of West Florida), and both of us.

There were various issues and questions discussed in the Marketing Analytics sessions and especially in the special panel session; most of them related to the role of marketing analytics in the business and marketing academia, research, and practice. We will now briefly describe the most prominent issues that arose, which can be discussed in future research.

Anjala S. Krishen

anjala.krishen@unlv.edu

1 Lee Business School, University of Nevada, Las Vegas, 4505 Maryland Parkway, Las Vegas, NV 89154, USA

2 H. Wayne Huizenga College of Business and Entrepreneurship, Nova Southeastern University, 3301 College Ave., Fort Lauderdale, FL 33314, USA

\section{What is marketing analytics?}

There are various issues that create barriers for marketing analytics specialists and participants in the field that stem from a lack of clarification of the concept of marketing analytics itself as well as its relationship with the marketplace, marketing research, and marketing metrics. In the academic world, this lack of clarity creates confusion regarding the role of marketing analytics courses and programs, versus the classical marketing research courses that most universities normally offer in their curricula. It also presents a dilemma on whether this topic should find its way into graduate programs at the masters or doctoral levels and, if so, in which area-substantive or methodological? Regarding research, some discussions focus on which areas of marketing can benefit more from marketing analytics research and may be more suited to strengthen this domain. For practitioners, the issue is more related to whether marketing research can incorporate the latest marketing analytics and technological developments and maintain both relevance and rigor in its endeavors.

Overall, as shown in Fig. 1, there are a few inputs and processes related to marketing analytics that can be clarified for the benefit of marketing academics, researchers, and practitioners, for example:

- What is marketing analytics and how does it relate to market strategy and marketing research and their management of data?

- Where should the field of marketing analytics be placed within the curriculum of a business school?

- Should we focus on breadth or depth in departing marketing analytics knowledge? As such, is it a chapter in each of our courses or a course of its own? 


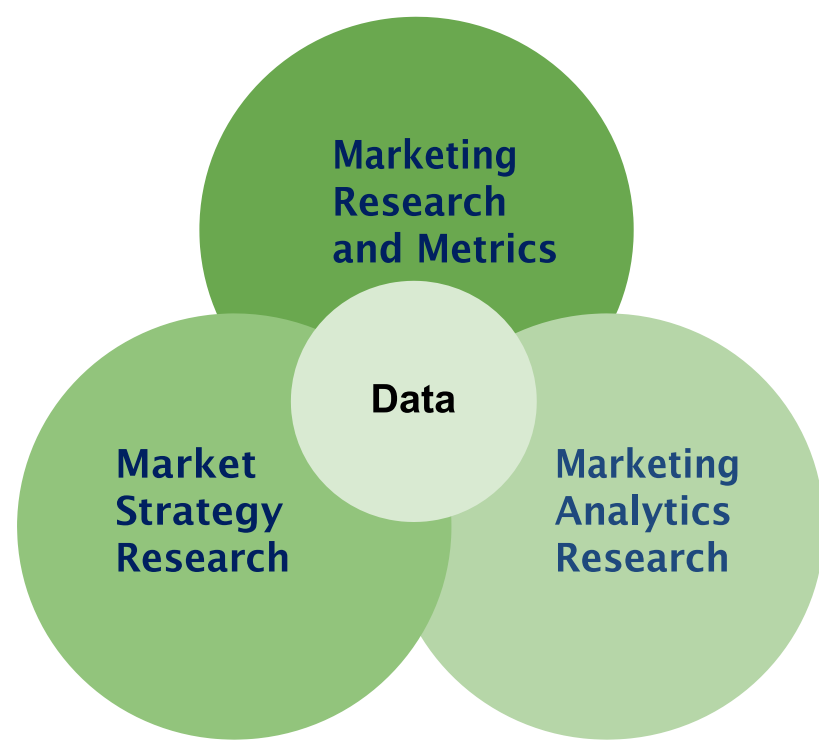

Fig. 1 Marketing analytics and research

- How is the role and placement of a marketing analytics specialist defined within a business school or marketing department?

- How can marketing analytics researchers better cooperate and evolve with marketing practitioners?

- What are the actionable ways that marketing analytics provides mechanisms and processes which connect data, information, and knowledge (Krishen and Petrescu 2018)?

\section{Marketing analytics in the business world}

A second major problem that surfaced in the debates on marketing analytics expands the dilemmas beyond the marketing domain. Even though the term marketing analytics is not new, considering that the Nielsen rating originated in the 1920s, the digital explosion has also created a widespread interest in digital analytics, big data, and data mining (Petrescu and Krishen 2017). As conference panel discussions revealed, business schools are trying to determine where to place marketing analytics, since the field spans multiple departments and is interdisciplinary and inclusive in content (Krishen and Petrescu 2017). In addition to fitting within a marketing department, the field of business analytics also includes management information systems (MIS) research and a new journal, Journal of Business Analytics, taking the perspective of operations management, would also be likely to publish marketing academic research. This ambiguity raises questions about which disciplines should house courses on this topic, which sciences (or journals) are best suited to research marketing analytics, and which business departments should manage marketing analytics in the corporate world. As Fig. 2 shows, negotiations are taking place amongst experts in multiple fields including decision science, economics, management of information systems, management, and, of course, marketing.

However, these issues could be avoided by studying and clarifying the topics we mentioned in the previous section, as well as some additional questions:

- How does marketing analytics combine with research methods, statistics, and data science and how much of marketing analytics is marketing?

- How can new technologies in data science and MIS contribute to marketing analytics in research and practice?

- How interdisciplinary is marketing analytics?

- How can academic and business departments better collaborate for marketing analytics-based decisionmaking?

We at the Journal of Marketing Analytics welcome research studies and constructive interdisciplinary debates on the aforementioned topics that can define, delineate, and bring progress to the field of marketing analytics. We also want to provide a cautionary note that applies to marketing analytics research, just as it does with all marketing research-metrics and data are empty shells without proper theories and interpretations behind them.

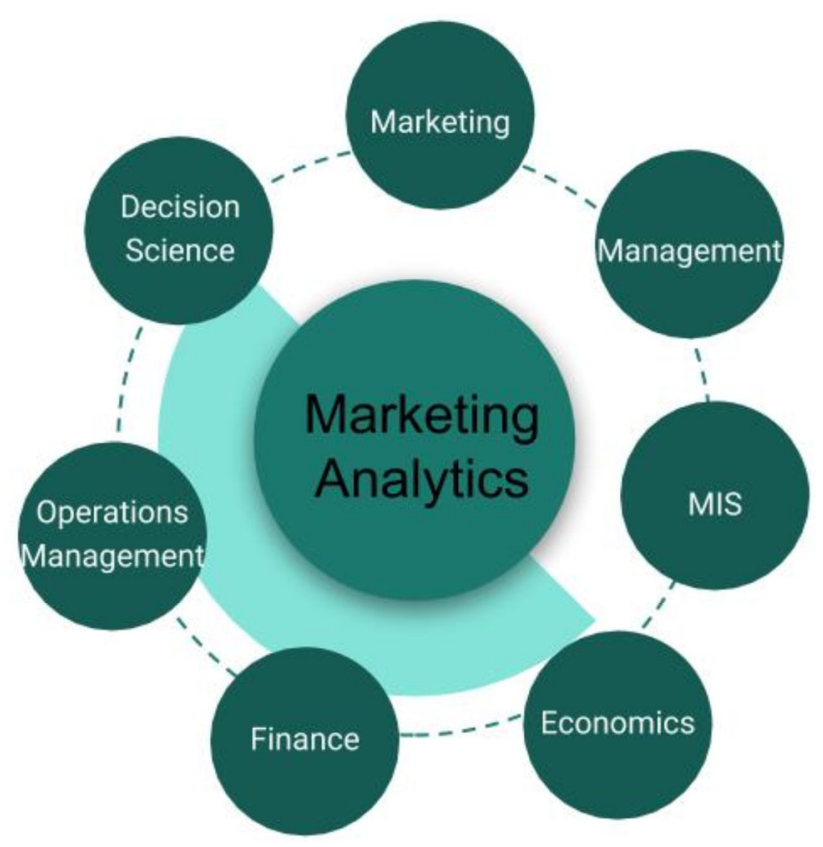

Fig. 2 Marketing analytics and business disciplines 


\section{References}

Krishen, A.S., and M. Petrescu. 2017. The world of analytics: Interdisciplinary, inclusive, insightful, and influential. Journal of Marketing Analytics 5 (1): 1-4.

Krishen, A.S., and M. Petrescu. 2018. Analytics from our scholarly closets: The connections between data, information, and knowledge. Journal of Marketing Analytics 6 (1): 1-5. https://doi.org/ 10.1057/s41270-018-0029-7.

Petrescu, M., and A.S. Krishen. 2017. Marketing analytics: From practice to academia. Journal of Marketing Analytics 5 (1): $45-46$.

Anjala S. Krishen, Professor of Marketing at University of Nevada, Las Vegas, has a B.S. in Electrical Engineering from Rice University, and an M.S. Marketing, MBA, and Ph.D. from Virginia Tech. Krishen held management positions for 13-years before pursuing a doctorate. As of 2018, she has published over 50 peer-reviewed journal papers in journals including Journal of Business Research, Psychology \& Marketing, Information \& Management, European Journal of Marketing, Journal of Travel \& Tourism Marketing, and Journal of Marketing Education. In 2016, she gave a TEDx talk (at UNR) titled, "Opposition: The light outside of the dark box," and a UNLV Creates speech entitled, "Consuming to Creating, Watching to Doing, Seeing to Being." As of 2018, she has completed over 55 marathons, seven ultramarathons, three 100 milers, and has a black belt in Taekwondo.

Maria Petrescu is Associate Professor of Marketing at Nova Southeastern University. Her research interests are digital marketing, marketing communications, and marketing analytics. She has a Ph.D. in Business Administration and Marketing from Florida Atlantic University. She participated and published in prestigious conferences and publications, including Journal of Marketing Management, Journal of Retailing and Consumer Services, Journal of Product and Brand Management, and Journal of Internet Commerce. In 2014 she also published a book on Viral marketing and social networks. 